12,14

\title{
Монодисперсные сферические мезо-макропористые частицы кремнезема: синтез и адсорбция биомакромолекул
}

\author{
() Е.Ю. Стовпяга ${ }^{1}$, С.А. Грудинкин ${ }^{1,2}$, Д.А. Курдюков ${ }^{1}$, Ю.А. Кукушкина ${ }^{1}$, А.В. Нащекин ${ }^{1}$, \\ B.B. Соколов ${ }^{1}$, D.R. Yakovlev ${ }^{3}$, В.Г. Голубев ${ }^{1}$ \\ ${ }^{1}$ Физико-технический институт им. А.Ф. Иофрфе РАН, \\ Санкт-Петербург, Россия \\ ${ }^{2}$ Санкт-Петербургский национальный исследовательский университет \\ информационных технологий, механики и оптики, \\ Санкт-Петербург, Россия \\ ${ }^{3}$ Experimentelle Physik 2, Technische Universität Dortmund, \\ Dortmund, Germany \\ E-mail: kattrof@gvg.ioffe.ru
}

(Поступила в Редакцию 18 апреля 2016 г.)

Методом химического травления в автоклаве получены монодисперсные сферические частицы кремнезема, содержащие крупные мезопоры (более $10 \mathrm{~nm}$ ) и макропоры (до $100 \mathrm{~nm}$ ). Разработан метод введения в поры молекул глобулярного белка миоглобина. Метод заполнения основан на высокой адсорбционной способности развитой внутренней пористой структуры частиц. Исследованы структура и адсорбционные свойства полученных материалов.

Работа выполнена при финансовой поддержке РФФИ (№ 15-52-12011) и DFG в рамках ICRC TRR 160.

\section{1. Введение}

Выделение молекул белков из биологического материала (например, органов и тканей) является важной задачей для изучения взаимосвязи между первичной пространственной структурой белка и его функцией, а также для биомедицинских приложений [1,2]. Для выделения белков часто применяется метод жидкостной хроматографии, основанный на распределении веществ между двумя фазами (жидкостью и адсорбентом) благодаря многократным актам адсорбции-десорбции. В последнее время в качестве адсорбентов биологических молекул стал широко использоваться мезопористый кремнезем MCM-41 [3] и SBA-15 [2,3], имеющий внутреннюю систему пор. Характерный размер пор для частиц МСМ-41 варьируется от 2 до $4 \mathrm{~nm}$, для материала SBA-15 может достигать $30 \mathrm{~nm}$, что определяется размерами молекул органических порообразующих темплатов, используемых при синтезе $[4,5]$. В связи с этим SBA-15 применяется для адсорбции биологических молекул с большими линейными размерами, например белков и фрагментов рибонуклеиновых кислот, с целью их выделения, последующей стабилизации и (или) разделения $[3,6]$.

В хроматографических колонках SBA-15 используется редко, поскольку частицы полидисперсны, имеют несферическую (червеобразную) форму; обычно в качестве неподвижной фазы применяются сферические пористые гранулы. Гранулы должны быть сопоставимого размера, в идеале монодисперсными, для обеспечения одинаковой скорости движения жидкости во всем объеме колонки. Перспективным материалом для хроматографии являются монодисперсные сферические мезопористые частицы кремнезема (МСМЧК) [7,8]. Монодисперсность частиц обеспечит их плотнейшую упаковку в колонке, что приведет к одинаковому количеству актов адсорбциидесорбции в любой точке колонки, а следовательно, увеличит эффективность разделения смесей белков.

Получение МСМЧК с размером пор свыше $5 \mathrm{~nm}$ является сложной задачей, поскольку увеличение концентрации и введение дополнительных порообразующих веществ в реакционную смесь приводят к образованию несферических полидисперсных частиц [9]. В настоящей работе предложен метод получения мезо-макропористых сферических монодисперсных частиц кремнезема (ММСМЧК). Средний размер пор в ММСМЧК контролируемо варьировался путем травления МСМЧК (диаметр пор $3 \mathrm{~nm}$ ) в спирто-аммиачной среде в автоклаве при температуре $120^{\circ} \mathrm{C}$. Продолжительность травления составляла от $10 \mathrm{~min}$ до $24 \mathrm{~h}$. Синтезированные частицы содержат крупные мезопоры размером более $10 \mathrm{~nm}$ и макропоры до $100 \mathrm{~nm}$. Микроскопическими методами показано, что процесс травления не влияет на форму и разброс размеров частиц. Проведено адсорбционно-структурное исследование изменений внутренней структуры частиц в процессе формирования крупных пор. Для исследования адсорбционной способности ММСМЧК в качестве модельного объекта был выбран глобулярный белок миоглобин $(\mathrm{Mb})$, размер молекул которого составляет $2.1 \times 3.5 \times 4.4 \mathrm{~nm}$ [2]. Методом ИК-спектроскопии показано, что синтезированные ММСМЧК эффективно сорбируют и удерживают молекулы миоглобина.

\section{2. Методика эксперимента}

МСМЧК с диаметром пор $3 \mathrm{~nm}$ синтезировались согласно разработанной нами методике [8]. Для по- 
лучения мезо-макропористых частиц приготавливались суспензии, состоящие из МСМЧК $(0.5 \mathrm{~g}), 1 \mathrm{~g} \mathrm{C} \mathrm{C}_{2} \mathrm{OH}$ $\left(95.7\right.$ vol.\%) и $4 \mathrm{~g} \quad \mathrm{NH}_{3} \cdot \mathrm{H}_{2} \mathrm{O} \quad\left(\mathrm{NH}_{3}\right.$ в $\mathrm{H}_{2} \mathrm{O}, 24 \mathrm{wt} . \%$, $\geq 99.99 \%$ ). Полученные суспензии помещались в автоклав и выдерживались при температуре $120^{\circ} \mathrm{C}$ в течение $10 \mathrm{~min}, 30 \mathrm{~min}, 1 \mathrm{~h}, 2 \mathrm{~h}$ и $24 \mathrm{~h}$. Обработанные таким образом частицы три раза промывались в деионизованной воде $(10 \mathrm{M} \Omega)$ и высушивались при температуpe $100^{\circ} \mathrm{C}$.

В настоящей работе исследовалась адсорбция белка миоглобина (Aldrich, лиофилизированный порошок, молекулярный вес $17 \mathrm{kDa}$ ) частицами после $30 \mathrm{~min}$ травления в автоклаве. На первом этапе методом седиментации подготавливались коллоидные пленки из ММСМЧК на подложках кристаллического кремния марки КДБ-10. Затем полученные пленки пропитывались в $0.01 \mathrm{wt} . \%$ водном растворе миоглобина. Пленка находилась в закрытом боксе в контакте с раствором в течение $2 \mathrm{~h}$, после чего пленка высушивалась на воздухе при комнатной температуре. Затем пленка промывалась в деионизованной воде в течение $2 \mathrm{~h}$ и снова высушивалась. Для подтверждения нахождения $\mathrm{Mb}$ в порах частиц использовалась ИК-спектроскопия. Регистрировались ИК-спектры незаполненной пленки, пленки, пропитанной в растворе $\mathrm{Mb}$, отмытой пленки и чистого миоглобина.

Адсорбционно-структурные исследования были проведены на анализаторе ASAP 2020 фирмы Micromeritics при температуре $77 \mathrm{~K}$ с применением азота в качестве адсорбционного газа. Размер пор рассчитывался с помощью встроенного программного обеспечения с использованием классической теории функционала плотности. Для обработки размеров пор МСМЧК и ММСМЧК после $10 \mathrm{~min}$ травления в автоклаве использовалась модель цилиндрических пор, для ММСМЧК после $30 \mathrm{~min}$ травления - модель щелевидных пор. Расчет изотерм адсорбции по указанным моделям наилучшим образом совпадал с экспериментальными данными во всем диапазоне относительных давлений.

ИК-спектры пропускания измерялись на Фурьеспектрометре „IFS Bruker 113v“. Спектры регистрировались в области частот $400-4000 \mathrm{~cm}^{-1}$ с использованием DTGS (дейтерированный триглицинсульфат)-детектора. Спектральное разрешение составляло $4 \mathrm{~cm}^{-1}$. Спектры получены с участка образца размером $1.25 \times 1.25 \mathrm{~mm}$. Измерения спектров пропускания проводились в вакууме. Микроскопические исследования выполнялись с помощью атомно-силового микроскопа NT-MDT SMENA в полуконтактном режиме и сканирующего электронного микроскопа JEOL JSM7001F.

\section{3. Результаты и обсуждение}

Ранее было показано, что МСМЧК состоят из кластеров плотноупакованных трубок $\mathrm{SiO}_{2}$ с внутренним диаметром $3.1 \mathrm{~nm}$ и внешним диаметром $4.3 \mathrm{~nm}$ (рис. $1, a, b)$.

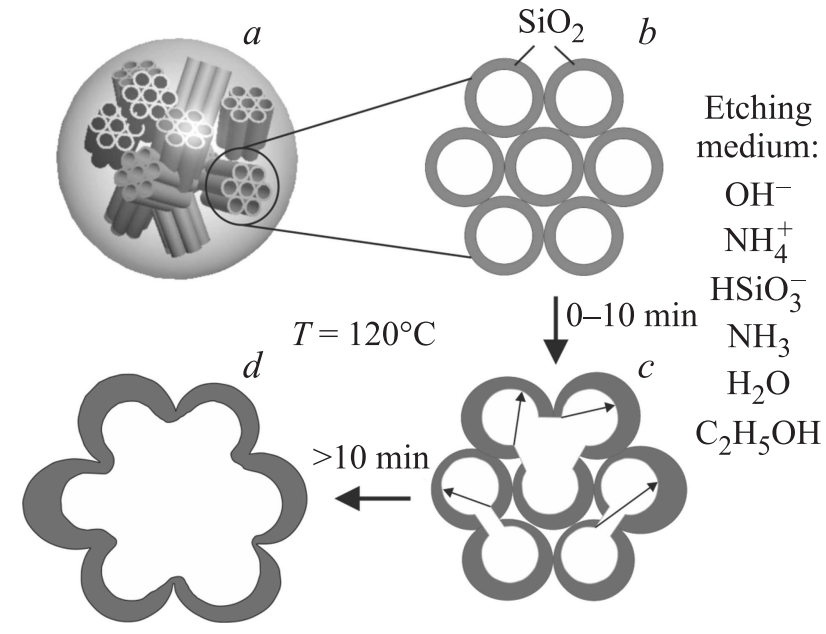

Рис. 1. Схематическое изображение процесса травления МСМЧК в автоклаве в спирто-аммиачной среде: $a$ - сферическая частица кремнезема, состоящая из кластеров плотноупакованных трубок $\mathrm{SiO}_{2}$ (диаметр пор $3 \mathrm{~nm}$ ), $b$ - поперечное сечение одного кластера, $c$ - травление стенок трубок $\mathrm{SiO}_{2}$ (стрелками показан перенос $\mathrm{SiO}_{2}$ с мест с наибольшей химической активностью к внешним границам кластера), $d$ - образование крупных пор, сравнимых с размером кластеров. Указаны состав травителя, температура и время травления.

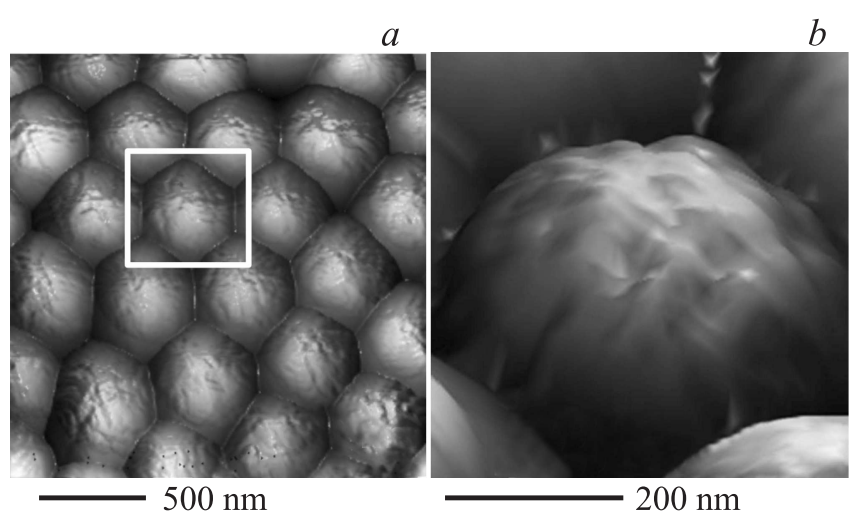

Рис. 2. АСМ-изображения МСМЧК на кремниевой подложке после травления частиц в автоклаве в спирто-аммиачной среде при $120^{\circ} \mathrm{C}$ в течение $24 \mathrm{~h}$. Светлым квадратом на части $a$ обозначена область, представленная в увеличенном виде на части $b$.

Размер кластеров составляет $\sim 15 \mathrm{~nm}$. В процессе синтеза в реакционной смеси происходят образование и контролируемая коагуляция кластеров в субмикронные монодисперсные сферические частицы [8]. Установлено, что МСМЧК после любого времени обработки от $10 \mathrm{~min}$ до $24 \mathrm{~h}$ в спирто-аммиачной среде в автоклаве при $120^{\circ} \mathrm{C}$ сохраняют сферическую форму, что подтверждено данными атомно-силовой микроскопии (АСМ) и сканирующей электронной микроскопии (СЭМ) (рис. 2 и 3). Отметим плотнейшую упаковку частиц, наблюдаемую на АСМ-изображении (рис. 2,a). Упорядочение частиц с образованием плотноупакованных опалоподобных кол- 

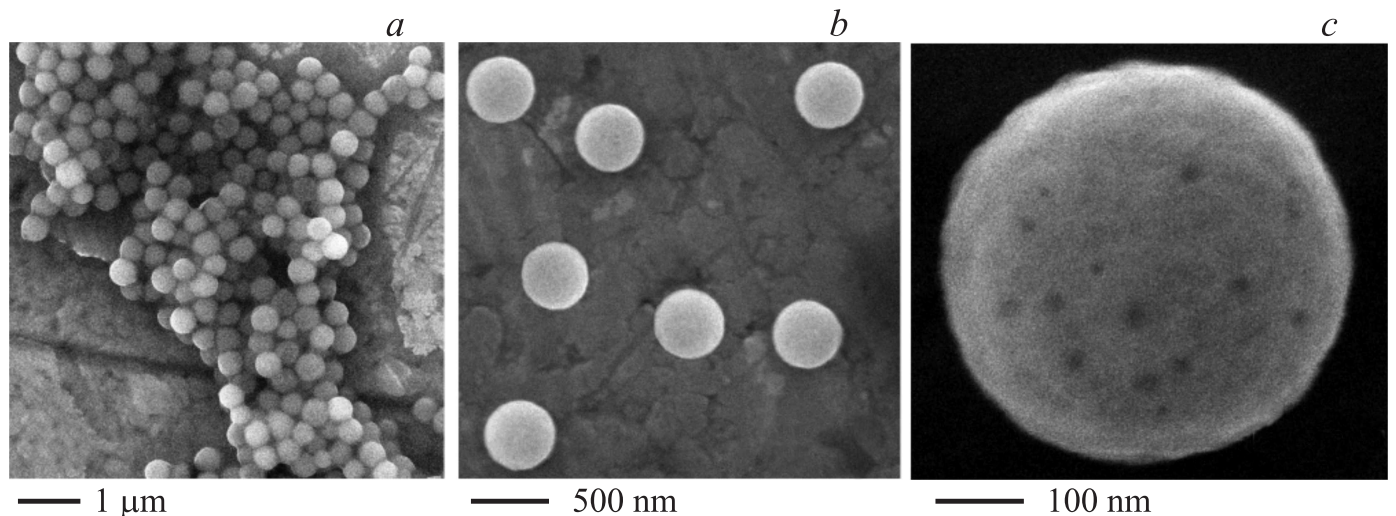

Рис. 3. СЭМ-изображения $(a-c)$ МСМЧК на кремниевой подложке после травления частиц в автоклаве в спирто-аммиачной среде при $120^{\circ} \mathrm{C}$ в течение $24 \mathrm{~h}$.

лоидных кристаллов имеет место при среднеквадратичном отклонении диаметров частиц менее $6 \%[8,10,11]$.

Рассмотрим возможный механизм формирования крупных мезопор (размером более $10 \mathrm{~nm}$ ) при травлении МСМЧК в спирто-водно-аммиачной смеси в автоклаве. Мы полагаем, что образование крупных мезопор происходит посредством объединения соседних трехнанометровых пор внутри кластера, т.е. за счет удаления стенок между соседними трубками $\mathrm{SiO}_{2}$ (рис. 1). Растворение $\mathrm{SiO}_{2}$ начинается с мест с наибольшей химической активностью, по-видимому с тех областей, где в кремнекислородном каркасе имеются оборванные связи, образовавшие одиночные силанолы [12]. Массоперенос направлен к внешним границам кластера, как показано стрелками на рис. 1, с. Данный процесс можно описать следующими уравнениями:

$$
\begin{gathered}
\mathrm{NH}_{3} \cdot \mathrm{H}_{2} \mathrm{O} \leftrightarrow \mathrm{NH}_{4}^{+}+\mathrm{OH}^{-}, \\
\mathrm{SiO}_{2}+\mathrm{OH}^{-} \leftrightarrow \mathrm{HSiO}_{3}^{-} .
\end{gathered}
$$

На первом этапе происходит обратимая диссоциация слабого основания с образованием ионов $\mathrm{NH}_{4}^{+}$и $\mathrm{OH}^{-}$. При взаимодействии $\mathrm{OH}^{-}$со стенками трубок $\mathrm{SiO}_{2}$ толщиной $\sim 1 \mathrm{~nm}$ происходит образование ионов $\mathrm{HSiO}_{3}^{-}$. Гидросиликат-ионы переносятся через жидкую фазу к внешним границам кластера, где вновь образуется аморфный $\mathrm{SiO}_{2}$ посредством реакции, обратной реакции (2). Образующийся пористый кремнезем является менее дисперсным, поэтому термодинамически он более устойчив, чем исходные МСМЧК. Стенки формирующихся более крупных пор имеют меньшую кривизну, их поверхность менее химически активна. Подобный механизм травления наблюдали авторы работы [13] при обработке частиц монокристаллического кремния в спирто-аммиачной среде.

На рис. 4, $а$ представлены изотермы адсорбции азота при $77 \mathrm{~K}$ для МСМЧК до (кривая 1 ) и после травления в автоклаве (кривые 2-6). Для МСМЧК с диаметром пор $3 \mathrm{~nm}$ характерна капиллярная конденсация при относительных давлениях $0.2 \leq p / p_{0} \leq 0.4$, проявляющаяся
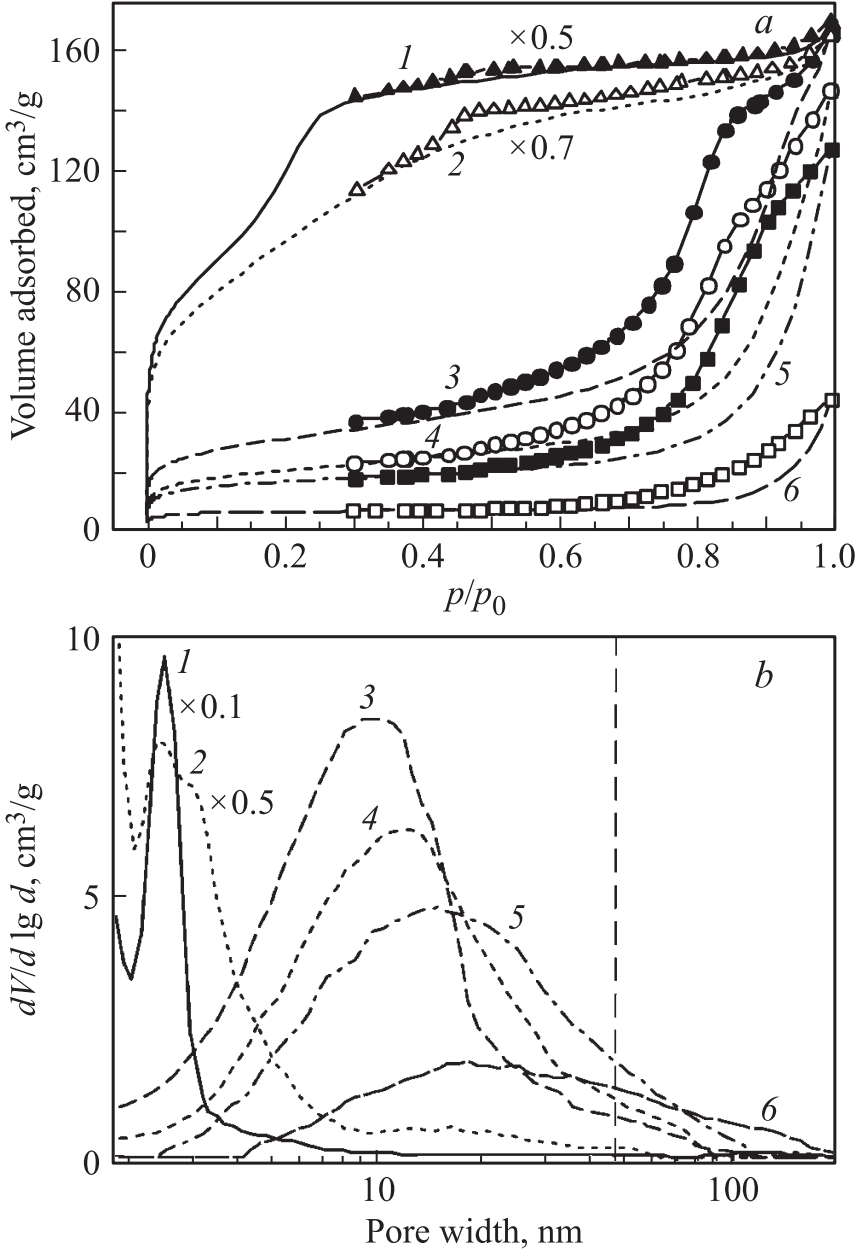

Рис. 4. Изотермы адсорбции азота при $77 \mathrm{~K}(a)$ и распределение пор по размерам $(b)$ для МСМЧК до $(1)$ и после травления в течение $10 \mathrm{~min}(2), 30 \mathrm{~min}(3), 1 \mathrm{~h} \mathrm{(4),}$ $2 \mathrm{~h}(5), 24 \mathrm{~h}(6)$. На части $а$ линиями показаны адсорбционные ветви, линиями с символами - десорбционные ветви. На части $b$ - вертикальная линия соответствует границе между мезо- и макропорами по классификации IUPAC. 
Характеристика синтезированных ММСМЧК

\begin{tabular}{c|c|c|c|c}
\hline $\begin{array}{c}\text { Время травления } \\
\text { МСМЧК в автоклаве }\end{array}$ & $\begin{array}{c}\text { Удельная } \\
\text { поверхность, } \mathrm{m}^{2} / \mathrm{g}\end{array}$ & $\begin{array}{c}\text { Объем } \\
\text { пор, } \mathrm{cm}^{3} / \mathrm{g}\end{array}$ & $\begin{array}{c}\text { Объем } \\
\text { мезопор, \% }\end{array}$ & $\begin{array}{c}\text { Объем } \\
\text { макропор, \% }\end{array}$ \\
\hline- & 850 & 0.45 & 100 & 0 \\
$10 \mathrm{~min}$ & 410 & 0.34 & 97 & 3 \\
$30 \mathrm{~min}$ & 120 & 0.24 & 96 & 7 \\
$1 \mathrm{~h}$ & 65 & 0.19 & 93 & 8 \\
$2 \mathrm{~h}$ & 55 & 0.17 & 92 & 75 \\
$2 \mathrm{~h}$ & 20 & 0.07 & & 25
\end{tabular}

на изотерме адсорбции в виде ступеньки (кривая 1). С увеличением времени травления в автоклаве от $10 \mathrm{~min}$ до $24 \mathrm{~h}$ на изотермах наблюдается появление петли гистерезиса в диапазоне более высоких относительных давлений $0.4 \leq p / p_{0} \leq 1.0$, что обусловлено капиллярной конденсацией в гораздо более крупных порах размером от $6 \mathrm{~nm} \mathrm{(кривая} \mathrm{2)} \mathrm{до} \mathrm{нескольких} \mathrm{десятков}$ нанометров (кривые 5,6). По-видимому, при временах травления более $1 \mathrm{~h}$ начинают травиться образованные в первые десятки минут поры размером $\sim 10 \mathrm{~nm}$, формируя мезопоры большего размера и макропоры размером до $\sim 100 \mathrm{~nm}$. Большее время травления стенок десятинанометровых мезопор, по-видимому, обусловлено их относительно невысокой (по сравнению с порами диаметром $3 \mathrm{~nm}$ ) химической активностью. Согласно классификации IUPAC, к мезопористым относятся материалы с размером пор в диапазоне от 2 до $50 \mathrm{~nm}$, к макропористым - свыше $50 \mathrm{~nm}$. Граница между мезопорами и макропорами по классификации IUPAC обозначена на рис. $4, b$ вертикальной штриховой линией. Видно, что кривые $3-6$, рис. $4, b$ соответствуют частицам, содержащим как мезо-, так и макропоры. На рис. 2, $b$ на поверхности частиц наблюдается шероховатость $(\sim 50 \mathrm{~nm})$, сравнимая с размером крупных пор. На рис. 3, $c$ видны круглые темные пятна, представляющие собой изображения крупных пор. Рассчитанные значения удельной поверхности по методу Брунауэра-ЭмметаТеллера, объема и размеров пор с использованием классической теории функционала плотности, а также объемное соотношение мезо- и макропор для частиц до и после травления в автоклаве сведены в таблицу.

Исследование адсорбции миоглобина в порах синтезированных частиц проведено с помощью ИК-спектроскопии. Сначала поры внутри ММСМЧК и поры между частицами пропитывались раствором миоглобина. Спектр частиц после пропитки Мb приведен на рис. 5 (кривая 2). Время выдержки составляло $2 \mathrm{~h}$, что достаточно для проникновения органических веществ в мезопоры и адсорбции [14]. Адсорбция миоглобина, по-видимому, была обусловлена электростатическим взаимодействием между заряженными участками поверхности стенок мезопор (силанольными группами) и заряженными участками белковой молекулы [15]. После высушивания пленки записывался ИК-спектр пропускания.
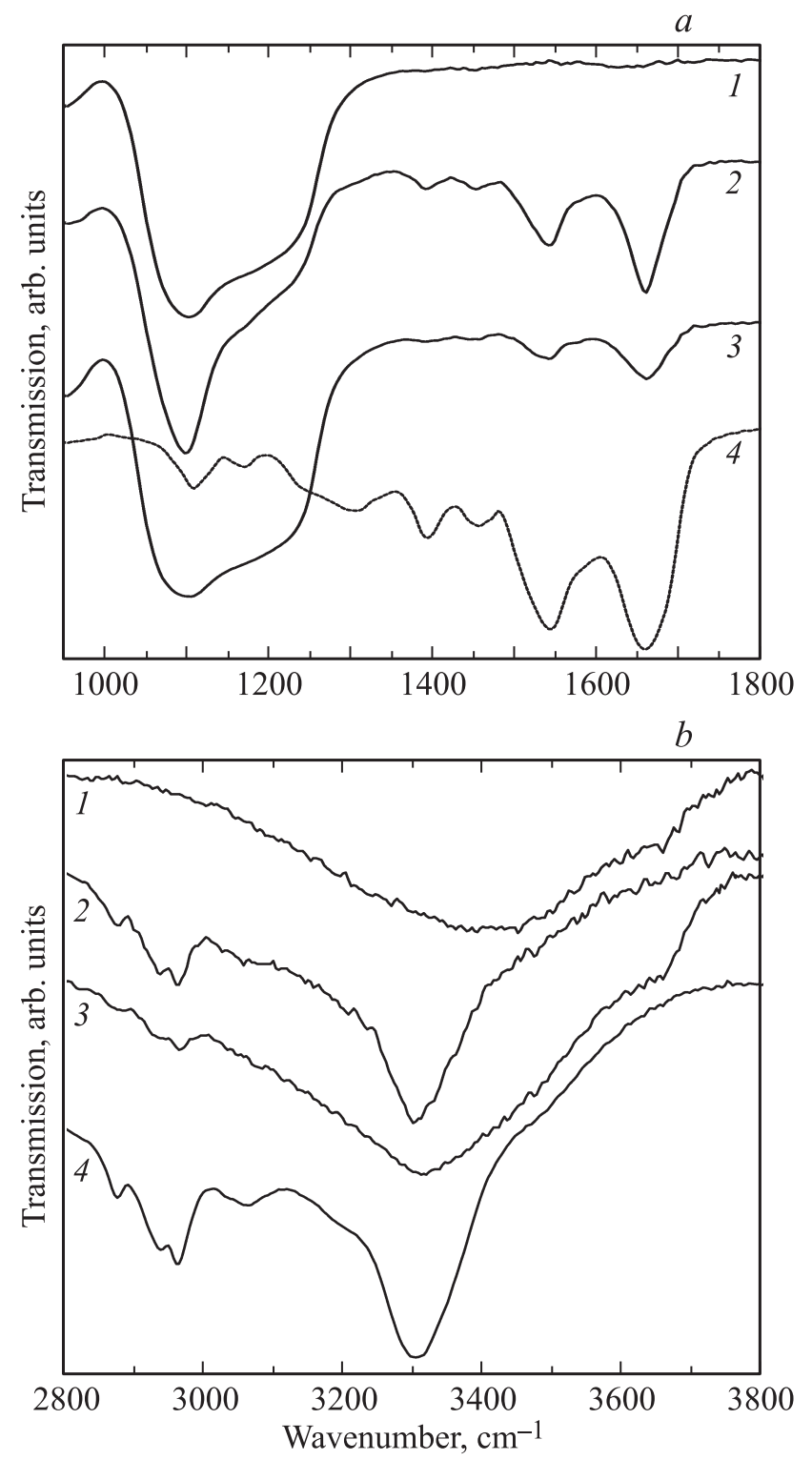

Рис. 5. ИК-спектры пропускания МСМЧК после травления в автоклаве в спирто-аммиачной среде при $120^{\circ} \mathrm{C}$ в течение $30 \min (1)$, их последующей пропитки в водном растворе миоглобина (2) и после отмывки (3), 4 - ИК-спектр миоглобина. Величина волнового вектора в диапазоне 950-1800 (a) и $2800-3800 \mathrm{~cm}^{-1}(b)$. 
После длительной отмывки пленки ММСМЧК в воде, во время которой Мb выходил из пространства между частицами в раствор, вновь записывался ИК-спектр (рис. 5, кривая 3). Как видно из рис. 5, для ММСМЧК после пропитки и ММСМЧК после отмывки наблюдаются полосы поглощения, характерные для Мb (кривая 4). Идентификация полос в спектрах проводилась на основе данных, приведенных в [16-18].

Рассмотрим ИК-спектр незаполненных ММСМЧК, полученных в результате травления в спирто-аммиачной среде в автоклаве в течение $30 \mathrm{~min}$. Интенсивная широкая полоса $1100 \mathrm{~cm}^{-1}$ соответствует валентным колебаниям $\mathrm{Si}-\mathrm{O}-\mathrm{Si}$. Спектр пропускания ММСМЧК в области 2800-3800 $\mathrm{cm}^{-1}$ (кривая 1 на рис. $5, b$ ) состоит из нескольких перекрывающихся полос, обусловленных колебаниями ОН в молекулах физически адсорбированной воды, соединенных водородными связями, и цепочками силанольных групп, также связанных между собой водородными связями (содержат более двух попарно связанных ОН-групп) $[12,19]$. Отметим, что характерная узкая полоса $3745 \mathrm{~cm}^{-1}$, соответствующая колебаниям ОН в одиночных силанольных группах, которая наблюдалась нами ранее [12] для МСМЧК (диаметр пор $3 \mathrm{~nm}$ ), отсутствует, а спектральная полоса $3650 \mathrm{~cm}^{-1}$, соответствующая колебаниям терминальных силанольных групп, слабо выражена. Отсутствие полосы $3745 \mathrm{~cm}^{-1}$ обусловлено, по-видимому, меньшим количеством дефектов кремнекислородного каркаса в стенках пор большего размера и соответственно меньшим количеством силанольных групп.

После адсорбции миоглобина в порах частиц в ИК-спектрах наблюдаются полосы, характерные для поглощения $\mathrm{Mb}$ (рис. 5, кривая 4). Три наиболее интенсивные полосы поглощения (рис. 5, кривые 2-4) соответствуют полосам амид I $\left(1660 \mathrm{~cm}^{-1}\right)$, амид II $\left(1542 \mathrm{~cm}^{-1}\right)$ и амид $A\left(3300 \mathrm{~cm}^{-1}\right)[16]$. Полоса амид I возникает в результате валентных колебаний пептидной связи $\mathrm{C}=\mathrm{O}$ в молекуле (структуре) миоглобина, валентных колебаний связи $\mathrm{C}-\mathrm{N}$ и деформационных колебаний связи N-H [16]. Полоса амид II возникает в результате плоскостных деформационных колебаний $\mathrm{N}-\mathrm{H}$-группы и валентных колебаний $\mathrm{C}-\mathrm{N}$-группы $[16,20]$. Полоса амид $A$ возникает в результате расщепления валентного колебания связи $\mathrm{N}-\mathrm{H}$, частота которого совпадает с удвоенной частотой колебания полосы амид II [16]. Полоса амид $B\left(3060 \mathrm{~cm}^{-1}\right)$ выражена слабо.

Моды деформационных колебаний $\mathrm{CH}_{3}$ наблюдаются на частотах 1390 и $1455 \mathrm{~cm}^{-1}$, моды деформационных колебаний $\mathrm{CH}_{2}$ - на частоте $1305 \mathrm{~cm}^{-1}$, моды ассиметричных валентных колебаний $\mathrm{CH}_{3}$ - на частоте $2961 \mathrm{~cm}^{-1}$, моды асимметричных валентных колебаний С-H на частотах 2874 и $2935 \mathrm{~cm}^{-1}$ [16]. Как видно из рис. 5 , относительная интенсивность полос Мb (по сравнению с интенсивностью полос ММСМЧК) после отмывки уменьшается. По-видимому, миоглобин выходит из пор между частицами, но остается адсорбированный $\mathrm{Mb}$ внутри пор ММСМЧК, что подтверждает высокую адсорбционную способность полученных частиц.
Монодисперсные сферические частицы кремнезема с управляемым размером пор до $100 \mathrm{~nm}$ могут применяться в качестве неподвижной фазы в хроматографии для разделения смесей белков и в качестве адсорбентов. Отметим, что внутренняя поверхность частиц может быть дополнительно функционализирована активными группами (например, $-\mathrm{NH}_{2},-\mathrm{SH}$ ), позволяющими селективно адсорбировать определенные белковые молекулы [6].

\section{4. Заключение}

Методом химического травления монодисперсных сферических мезопористых частиц кремнезема (диаметр пор $3 \mathrm{~nm}$ ) в спирто-аммиачной среде в автоклаве при температуре $120^{\circ} \mathrm{C}$ получены частицы, содержащие крупные мезопоры размером более $10 \mathrm{~nm}$ и макропоры до $100 \mathrm{~nm}$. Предложен механизм формирования мезои макропор за счет объединения соседних трехнанометровых пор в кластерах $\mathrm{SiO}_{2}$, образующих частицы. Микроскопическими методами показано, что в процессе травления до $24 \mathrm{~h}$ частицы сохраняют сферическую форму и монодисперсность. Адсорбционно-структурные исследования показали, что в частицах имеются одновременно мезо- и макропоры.

Методом ИК-спектроскопии исследована адсорбция глобулярного белка миоглобина мезо-макропористыми сферическими частицами кремнезема. Показано, что основные характерные полосы поглощения миоглобина присутствуют в ИК-спектрах как пленки, в которой миоглобин находился в порах и между частицами, так и отмытой пленки, что свидетельствует о сохранении высокой адсорбционной способности частиц после травления в автоклаве.

Авторы благодарят Д.А. Еурова за помощь в подготовке образцов для ИК-спектроскопии и обсуждение полученных результатов.

Исследование проведено с использованием оборудования регионального ЦКП „Материаловедение и диагностика в передовых технологиях“.

\section{Список литературы}

[1] M. Rabe, D. Verdes, S. Seeger. Adv. Colloid Interface. Sci. 162, 87 (2011).

[2] H.H.P. Yiu, C.H. Botting, N.P. Botting, P.A. Wright. Phys. Chem. Chem. Phys. 3, 2983 (2001).

[3] M. Colilla, M. Manzano, M. Vallet-Regì. Int. J. Nanomedicine 3, 403 (2008).

[4] J.S. Beck, J.C. Vartuli, W.J. Roth, M.E. Leonowicz, C.T. Kresge, K.D. Schmitt, T.W.C. Chu, D.H. Olson, E.W. Sheppard. J. Am. Chem. Soc. 114, 10834 (1992).

[5] D. Zhao, J. Feng, Q. Huo, N. Melosh, G.H. Fredrick, B.F. Chmelka, G.D. Stucky. Science 279, 548 (1998).

[6] Y.J. Han, G.D. Stucky, A. Butler. J. Am. Chem. Soc. 121, 9897 (1999). 
[7] Е.Ю. Трофимова, Д.А. Курдюков, Ю.А. Кукушкина, М.А. Яговкина, В.Г. Голубев. ФХС 37, 38 (2011).

[8] E.Yu. Trofimova, D.A. Kurdyukov, S.A. Yakovlev, D.A. Kirilenko, Yu.A. Kukushkina, A.V. Nashchekin, A.A. Sitnikova, M.A. Yagovkina, V.G. Golubev. Nanotechnology 24, 155601 (2013).

[9] Е.Ю. Стовпяга, Д.А. Курдюков, Ю.А. Кукушкина, В.В. Соколов, М.А. Яговкина. ФХС 41, 424 (2015).

[10] P. Jiang, J.F. Bertone, K.S. Hwang, V.L. Colvin. Chem. Mater. 11, 2132 (1999).

[11] Е.Ю. Трофимова, А.Е. Алексенский, С.А. Грудинкин, И.В. Коркин, Д.А. Курдюков, В.Г. Голубев. Коллоид. журн. 73, 535 (2011).

[12] Д.А. Еуров, С.А. Грудинкин, Д.А. Курдюков, А.В. Медведев, Е.Ю. Стовпяга, В.Г. Голубев. Письма в ЖТФ 41, 19, 6 (2015).

[13] J. Niu, S. Zhang, Y. Niu, R. Song, H. Song, X. Chen, J. Zhou, S. Hong. RSC Adv. 4, 29435 (2014).

[14] Е.Ю. Трофимова, С.А. Грудинкин, Ю.А. Кукушкина, Д.А. Курдюков, А.В. Медведев, М.А. Яговкина, В.Г. Голубев. ФТТ 54, 1220 (2012).

[15] J.D. Andrade. Surface and interfacial aspects of biomedical polymers, V. 2. Protein Adsorption. Plenum, N.Y. (1985). $80 \mathrm{p}$.

[16] B. Stuart. Infrared spectroscopy: fundamentals and applications. John Wiley \& Sons, Ltd., The Atrium, Southern Gate, Chichester, West Sussex, England (2004). 244 p.

[17] J. Kong, S. Yu. Acta Biochim. Biophys. Sin. 39, 549 (2007).

[18] Д.А. Еуров, С.А. Грудинкин, Д.А. Курдюков, В.Г. Голубев. ФTT 57, 2031 (2015).

[19] P. Innocenzi. J. Non-Cryst. Solids 316, 309 (2003).

[20] M. Dong, Z. Wu, M. Lu, Z. Wang, Z. Li. Int. J. Mol. Sci. 13, 11443 (2012). 